Working Papers on Environmental Sciences

\title{
Consumer Valuation of Energy-Saving Features of Residential Air Conditioners with Hedonic and Choice Models
}

\author{
Shigeru Matsumoto ${ }^{1}$
}

\begin{abstract}
Affiliations:
${ }^{1}$ Visiting Researcher: Institut de Ciència i Tecnologia Ambientals (ICTA), Universitat Autònoma de Barcelona (UAB), Facultat de Ciències, Campus de la UAB, 08193 Bellaterra (Cerdanyola del Vallès), Spain

Professor: Department of Economics, Aoyama Gakuin University, Room 828 Building 8, 4-4-25 Shibuya, Shibuya-ku, Tokyo 150-8366, Japan
\end{abstract}

Contact: Shigeru Matsumoto <t71092@aoyamagakuin.jp>

Date: 27-05-2015

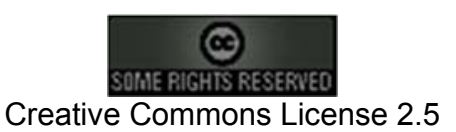


Refer to as:

Author: $\quad$ S. Matsumoto

Year: $\quad 2015$

Title: $\quad$ Consumer Valuation of Energy-Saving Features of Residential Air Conditioners with Hedonic and Choice Models

Working Papers on Environmental Sciences

Institut de Ciència i Tecnologia Ambientals (ICTA)

Edifici Cn, Campus UAB

08193 Cerdanyola del Vallès, Spain

Tel: (+34) 935812974

http://icta.uab.cat

icta@uab.cat

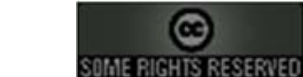




\title{
Consumer Valuation of Energy-Saving Features of Residential Air Conditioners with Hedonic and Choice Models
}

\section{Shigeru Matsumoto}

Visiting Researcher: Institut de Ciència i Tecnologia Ambientals (ICTA), Universitat Autònoma de Barcelona (UAB), Facultat de Ciències, Campus de la UAB, 08193 Bellaterra (Cerdanyola del Vallès), Spain Professor: Department of Economics, Aoyama Gakuin University, Room 828 Building 8, 4-4-25 Shibuya, Shibuya-ku, Tokyo 150-8366, Japan

\begin{abstract}
The promotion of energy-efficient appliances is necessary to reduce the energetic and environmental burden of the household sector. However, many studies have reported that a typical consumer underestimates the benefits of energy-saving investment on the purchase of household electric appliances. To analyze this energy-efficiency gap problem, many scholars have estimated implicit discount rates that consumers use for energy-consuming durables. Although both hedonic and choice models have been used in previous studies, a comparison between two models has not yet been done. This study uses point of sale data about Japanese residential air conditioners and estimates implicit discounts rates with both hedonic and choice models. Both models demonstrate that a typical consumer underinvests in energy efficiency. Although choice models estimate a lower implicit discount rate than hedonic models, the latter models estimate the values of other product characteristics more consistently than choice models.
\end{abstract}

Keywords: Integrated Assessment, Biophysical Economics, Sustainability, Power-Supply Systems, Nuclear Energy, Fossil Energy. 


\section{Contents}

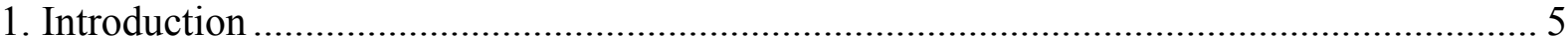

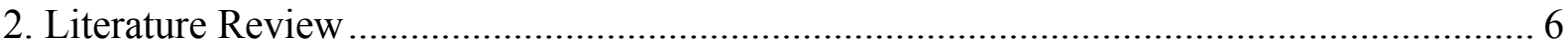

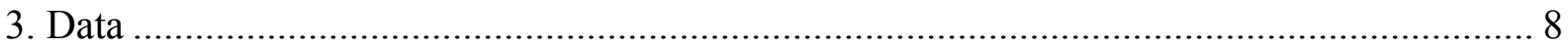

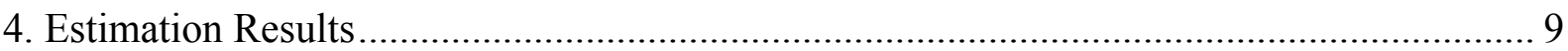

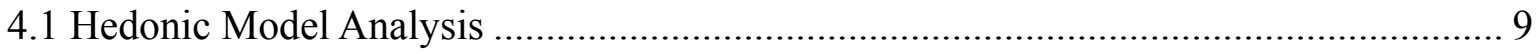

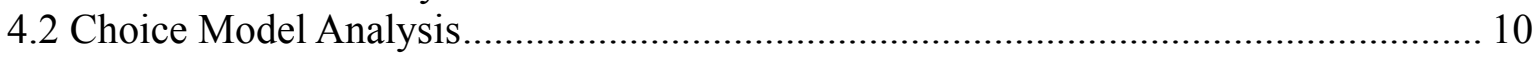

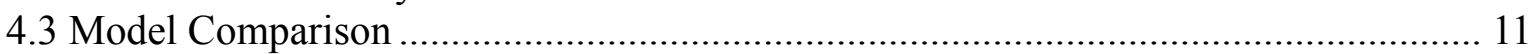

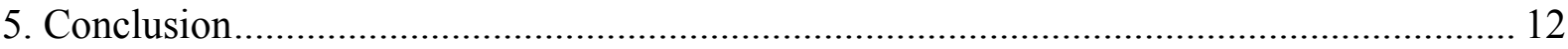

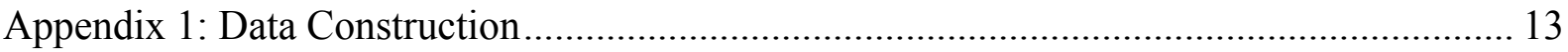

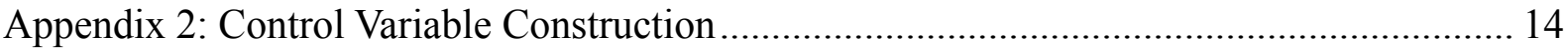

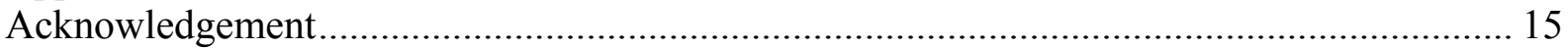

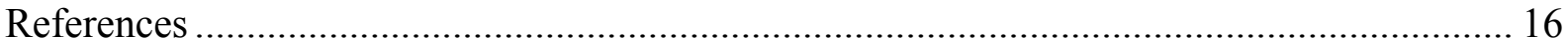




\section{Introduction}

When purchasing energy-consuming durables, such as home appliances and vehicles, a consumer compares their electricity consumption and fuel economy with their prices. If $\mathrm{s} / \mathrm{he}$ expects that $\mathrm{s} / \mathrm{h}$ e would get money back in future, $\mathrm{s} /$ he would choose an energy-efficient product even if the price were high. The problem is whether a consumer evaluates the benefit of the energy-saving investment in an efficient manner.

The discount rate that a consumer uses for energy-efficient durables is defined as the "implicit discount rate." Many scholars have estimated implicit discounts in various contexts to understand how consumers evaluate their energy-saving investment (Dubin, 1992; Sanstad, Hanemann, and Auffhammer, 2006; Train, 1985). Most studies report that a typical consumer uses a higher discount rate for energy-consuming durables and argue that s/he underinvests in energy saving. ${ }^{1}$ This phenomenon is named an "energy efficiency gap" by Jaffe and Stavins (1994).

When extracting implicit discount rates for energy-consuming durables from market data, researchers analyze the relationship between capital and operating costs of durables. Either hedonic or choice models have been used for empirical analysis. ${ }^{2}$ Hedonic models analyze how the difference in operating cost is reflected in the capital cost. Choice models analyze how the operating and capital costs determine the choice of products (Train, 1985).

To derive consumer demand for energy efficiency, it is necessary to know how sociodemographic characteristics of households affect the valuation of energy efficiency of durables. Unfortunately, most market data include only information about sales and product characteristics. Consequently, previous studies have estimated the marginal effect of energy efficiency improvement on product price. However, it is well known that the estimated marginal effect does not coincide with consumers' willingness to pay (WTP) for energy efficiency.

In the choice model, researchers define an indirect utility function with observable factors, such as product price, characteristics, and energy efficiency measures, and then, include unobservable factors into a random term. However, some unobservable factors can be correlated with observable factors. For instance, unobservable product characteristics are correlated with the product price. In such a case, the standard independence assumption is violated and an endogeneity problem arises. Although many scholars have attempted a wide variety of instrumental variable (IV) approaches, there are still criticisms that the endogeneity problem has not been resolved adequately.

In some cases, consumers purchase two or more durables. We expect that the choice criteria for the second or third durable would be different from the choice criteria for the first durable. To examine the difference in the choice criteria, researchers need to know the order of purchase of the durables. Unfortunately, most market data do not include such information.

\footnotetext{
${ }^{1}$ By contrast, some of the studies that analyzed the fuel economy of vehicles reported that consumers overinvested (Greene, 2010).

${ }^{2}$ In addition, engineering and stated preference models are used for the estimation of implicit discount rates. In engineering models, the installation costs of energy efficient technologies are compared and the value of resulting energy efficient investment is estimated. In stated preference models, surveys are conducted to elicit WTP for energy efficient investment.
}

\section{(2)}


Although the same durable is sold at different prices to different buyers, most market data do not include the record of each sale. Typical market data include only aggregated information, such as the total value and number of sales.

In addition, the technology progress of energy-consuming durables is very rapid and the set of the durables that consumers can purchase changes within a short time period. In choice model analysis, the choice set needs to be addressed while in hedonic model analysis, the sales number needs to be taken account of.

To this end, in considering the characteristics of market data, we should state that researchers have estimated implicit discount rates under strong assumptions. Perhaps partly because of this, previous studies have observed a large variation in the implicit discount rate (Sanstad, Hanemann, and Auffhammer, 2006). Nevertheless, surprisingly, no study has used the same dataset to compare the results between two models. Then, the following questions arise. Can we show that an implicit discount rate is higher than the interest rate applied for the conventional investment project regardless of the model selection? Which model's estimate of the implicit discount rate is higher and which is lower? The purpose of this study is to answer these questions.

The rest of the paper is organized as follows. In Section 2, we provide a brief literature review about implicit discount rates. In Section 3, we explain our dataset. This study analyzes the point of sale (POS) data of Japanese residential air conditioners (ACs). Section 4 presents and compares the estimation results of hedonic and choice models. Section 5 concludes the paper.

\section{Literature Review}

Many scholars have estimated implicit discount rates for various energy-consuming durables. Table 1 summarizes the estimations of household durables.

Table 1 shows that the size of the estimated implicit discount rates varies widely across studies. Some studies have reported that the estimated discount rate is only $2 \%$ while others have reported that it exceeded $100 \%$.

The majority of the studies were conducted between the late 1970s and early 1980s; this is the period after the oil shock, when energy conservation measures were focused on strongly. Although a wide variety of energy conservation measures have been introduced in recent years, and there are many studies that have been conducted in the United States (US), there is only a limited number of studies globally. ${ }^{3}$ The energy consumption of US households is substantially higher than that of other countries. Therefore, the studies in the US can be considered as research conducted in a special region. ${ }^{4}$

When analyzing household data, researchers have found that low-income households have higher discount rates than high-income households do (Train, 1985). This may be because low-income households cannot afford energy-efficient appliances owing to the

\footnotetext{
${ }^{3}$ For instance, Energy Star Label was introduced in the US in 1992.

${ }^{4}$ While the average per capita energy consumption of OECD counties is 191.25 million British thermal units (Btu), that of the US is 312.79 million Btu (US Energy Information Administration, 2011).
} 
liquidity constraint. ${ }^{5}$

Choice models are used frequently for appliance analyses while hedonic models are used less frequently. On the other hand, hedonic models have been used for the analysis of consumer valuations of the fuel economy (Arguea, Hsiao, and Taylor, 1994; Espey and Nair, 2005; Fan and Rubin, 2009; Fifer and Bunn, 2009; McManus, 2007). Greene (2010) conducts a literature survey of consumer valuation of the fuel economy and reports that the implicit discount rates are estimated to be higher when hedonic models are applied.

This literature review shows that some studies estimate the implicit discount rates of multiple energy-consuming durables but no study compares the implicit discount rates between hedonic and choice models. In this study, we examine how consumer valuation over energy efficiency is influenced by the selection of empirical models. ${ }^{6}$

Table 1. Implicit Discount Rates of Household Durables

\begin{tabular}{|c|c|c|c|}
\hline Studies & Durables & Average Discount Rate & Model \\
\hline Cole and Fuller (1980, national survey) & Thermal shell measures & $26 \%$ & Choice Model \\
\hline \multirow[t]{2}{*}{ Arthur D. Little, Inc. (1984) } & Thermal shell measures & $32 \%$ & Choice Model \\
\hline & Window and door measures & $10 \%$ & Choice Model \\
\hline \multirow[t]{3}{*}{ Corum and O’Neal (1982) } & Thermal integrity of new homes (Gas-heated houses) & $10 \%$ & Engineering Model \\
\hline & (Oil-heated houses) & $14 \%$ & Engineering Mode1 \\
\hline & (Electricity-heated houses) & $19-21 \%$ & Engineering Model \\
\hline Goett (1978) & Space heating system and fuel type & $36 \%$ & Choice Model \\
\hline Berkovec, Hausman, and Rust (1983) & Space heating system and fuel type & $25 \%$ & Choice Model \\
\hline \multirow[t]{2}{*}{ Goett (1983) } & Space heating system and fuel type with central AC & $4.4 \%$ & Choice Model \\
\hline & without central AC & $25 \%$ & Choice Model \\
\hline Dubin (1985) & Space heating system and fuel type & $2-10 \%$ & Choice Model \\
\hline Dubin (1986) & Space heating system and fuel type & $6.5-10.5 \%$ & Choice Model \\
\hline Goett and McFadden (1982) & Space heating system and fuel type & $6.5-16 \%$ & Choice Model \\
\hline $\begin{array}{l}\text { Cambridge Systematics, Inc. and Charles } \\
\text { River Associates, Inc. (1988) }\end{array}$ & Furnace replacement & $67.6 \%$ & Choice Model \\
\hline Hausman (1979) & Air conditioning & $29 \%$ & Choice Model \\
\hline Goett (1983) & Air conditioning & $3.2 \%$ & Choice Model \\
\hline Morita, Matsumoto, and Tasaki (2014) & Air conditioning & $2-18 \%$ & Hedonic Model \\
\hline Cole and Fuller (1980) & Refrigerators & $61-108 \%$ & $?$ \\
\hline Gately (1980) & Refrigerators & $45-300 \%$ & Engineering Model \\
\hline Meier and Whittier (1983) & Refrigerators & $34-58 \%$ & Engineering Model \\
\hline Cohen, Glachant, and Söderberg (2014) & Refrigerators & $10.5 \%$ & Choice Model \\
\hline Goett (1983) & Cooling and water heating fuel type & $36 \%$ & Choice Model \\
\hline Goett and McFadden (1982) & Water heating fuel type & $67 \%$ & Choice Model \\
\hline Berkovec, Hausman, and Rust (1983) & Water heating fuel type & $33 \%$ & Choice Model \\
\hline Dubin (1985) & Water heating fuel type & $24 \%$ & Choice Model \\
\hline Lin, Hirst, and Cohn (1976) & Cooking fuel type & $7-31 \%$ & Choice Model \\
\hline
\end{tabular}

${ }^{5}$ Matsumoto and Omata (2015) find that the implicit discount rate in Vietnam is substantially higher than in developed countries. Then, they argue that the liquidity constraint in developing countries prohibits the promotion of energy efficient appliances.

${ }^{6}$ Dubin (1992) analyzes energy-saving investment for houses and argues that the comparison between hedonic and choice models is important if the problem of asymmetric information in the housing market is considered. A comparison of the models has been conducted outside of the energy efficiency literature. For instance, Palmquist and Israngkura (1999) compare the valuation of air quality between hedonic and choice models.

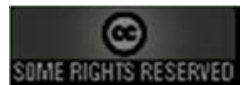


To examine consumer valuation for energy efficiency of durables with a hedonic model, we need to find a market in which the varieties of durables are large. By contrast, as the varieties increase, then the application of choice models becomes cumbersome. Therefore, we need to find a market in which the varieties of durables are in an appropriate range for both hedonic and choice models.

If consumers expect multiple functions for the product, then their decision criteria become complicated. For instance, it is less clear whether consumers purchase vehicles solely for transportation purposes or to flaunt their wealth (Veblen, 1899). Thus, it is desirable to analyze products that have a simple function.

Considering the abovementioned conditions, we analyze the Japanese residential AC market in this study. Households use ACs for space cooling and heating while other functions attached to the ACs are secondary. A wide variety of ACs is available in the Japanese market. However, room sizes are standardized in Japanese homes and ACs sold in Japanese market are designed to fit specific room sizes. ${ }^{7}$ Consequently, consumers choose an AC among those appropriate for their room size.

Table 2 shows the descriptive statistics of our dataset according to cooling capacity. It shows that the sales price of AC, $P$, increases as the room size increases. Similarly, the annual electricity consumption of $\mathrm{AC}, E C$, increases as the room size increases. ${ }^{8}$ As the room size increases, the required heating capacity $(H E A T)$ also increases. Thus, we find a positive relationship between cooling and heating capacities. In addition, Table 2 shows that the physical size of AC increases as cooling capacity increases.

\begin{tabular}{|c|c|c|c|c|c|c|c|c|c|c|c|c|c|}
\hline \multirow[t]{2}{*}{$\begin{array}{l}\text { Room } \\
\text { size } \\
\text { (jyo") }\end{array}$} & \multirow{2}{*}{$\begin{array}{c}\text { Cooling } \\
\text { Capacity } \\
\text { (CAP) } \\
(\mathrm{kW})\end{array}$} & \multicolumn{2}{|c|}{$\begin{array}{l}\text { No. models } \\
\mathrm{m}=1,-\cdots, \mathrm{M}\end{array}$} & \multicolumn{2}{|c|}{$\begin{array}{c}\text { Sales price }(P) \\
(\text { Yen })\end{array}$} & \multicolumn{2}{|c|}{$\begin{array}{c}\text { Annual electricity } \\
\text { consumption }(E C) \\
(\mathrm{kWh})\end{array}$} & \multicolumn{2}{|c|}{$\begin{array}{c}\text { Heating capacity } \\
\text { (HEAT) } \\
(\mathbf{k W})\end{array}$} & \multicolumn{2}{|c|}{$\begin{array}{c}\text { Physical size } \\
(\text { SIZE) } \\
\left(1000 \mathrm{~cm}^{3}\right)\end{array}$} & \multicolumn{2}{|c|}{$\begin{array}{c}\text { Days after market } \\
\text { release }(O L D) \\
(\text { days })\end{array}$} \\
\hline & & Min & Max & Average & Std. & Average & Std. & Average & Std. & Average & Std. & Average & Std. \\
\hline 6 & 2.2 & 56 & 113 & 71679.74 & 32599.44 & 785.47 & 90.18 & 2.38 & 0.15 & 54.25 & 8.40 & 451.26 & 292.49 \\
\hline 8 & 2.5 & 44 & 83 & 85843.30 & 34928.30 & 871.24 & 77.39 & 2.70 & 0.15 & 54.04 & 8.81 & 423.31 & 264.84 \\
\hline 10 & 2.8 & 60 & 119 & 95203.94 & 37667.22 & 967.10 & 96.56 & 3.20 & 0.29 & 55.65 & 8.64 & 449.05 & 291.35 \\
\hline 12 & 3.6 & 21 & 55 & 123057.60 & 39896.37 & 1378.80 & 152.26 & 4.20 & 0.00 & 57.68 & 7.42 & 379.96 & 247.72 \\
\hline 14 & 4.0 & 66 & 125 & 116585.80 & 41214.39 & 1544.91 & 187.03 & 4.98 & 0.11 & 56.75 & 7.92 & 461.21 & 292.70 \\
\hline 16 & 5.0 & 25 & 64 & 138983.10 & 43589.39 & 2062.74 & 254.02 & 6.16 & 0.19 & 58.52 & 8.36 & 483.69 & 307.20 \\
\hline 20 & 6.3 & 16 & 33 & 184630.80 & 36398.36 & 2515.06 & 455.91 & 6.94 & 1.22 & 64.06 & 7.36 & 428.97 & 287.64 \\
\hline 23 & 7.1 & 12 & 25 & 204101.90 & 37061.11 & 3185.20 & 166.44 & 7.74 & 0.36 & 63.48 & 6.32 & 495.36 & 400.94 \\
\hline
\end{tabular}

\footnotetext{
${ }^{7}$ The "tatami mat" is used as a measurement unit for traditional Japanese rooms. The size of one tatami mat is $1.74 \mathrm{~m}$ by $0.87 \mathrm{~m}$. Room sizes are standardized according to the number of tatami mats used. ${ }^{8}$ Annual electricity consumption, $E C$, is defined as the electricity required to run a specific $\mathrm{AC}$ under the following condition. It is assumed that an $\mathrm{AC}$ is used in a wooden house facing south located in the Tokyo area. The $\mathrm{AC}$ is used for space cooling to maintain the room temperature at $27^{\circ} \mathrm{C}$ from May 23 to October 4 while it is used for space heating to maintain the room temperature at $20^{\circ} \mathrm{C}$ from November 8 to April 16. It is further assumed that the AC is used for 18 hours per day (Japan Refrigeration and Air Conditioning Industry Association, 2014).
} 
The variable Days is the number of days after a specific AC model is released to the market. Since this average is about 450 days, many consumers purchase slightly old models.

In addition, Table 2 shows that the number of varieties is small in the large cooling capacity class. The application of the hedonic model is difficult in large classes. We analyze ACs in the classes of $2.2 \mathrm{~kW}, 2.5 \mathrm{~kW}, 2.8 \mathrm{~kW}, 3.6 \mathrm{~kW}$, and $4.0 \mathrm{~kW}$. The detail of the data construction is explained in Appendix 1.

\section{Estimation Results}

\subsection{Hedonic Model Analysis}

The purpose of this study is to compare the implicit discount rates between hedonic and choice models. Since a linear utility function is often used in choice model analyses, we assume the following linear hedonic model,

$$
A P_{m t}=\beta_{0}+\beta_{E C} E C_{m}+\beta_{O L D} O L D_{m t}+\beta_{N M} N M_{t}+\boldsymbol{B} \boldsymbol{X}_{m}+\varepsilon_{m t} .
$$

Here, $A P_{m t}$ is the average "acquisition" price" of the $m^{\text {th }} \mathrm{AC}$ model at period $t, E C_{m}$ is the annual electricity consumption, and $O L D_{m t}$ is the length of the period from the market release day to the sales day. In addition, we include the number of months from April $2008\left(N M_{t}\right)$ to control the price change. $\boldsymbol{X}_{m}$ is the vector of AC functions and $\varepsilon_{m t}$ is an error term.

If the prices of energy efficient ACs with low values of $E C_{m}$ are high, the coefficient of $\beta_{E C}$ is estimated to be negative in Equation 1. Using this coefficient, we discuss consumer valuation of energy saving.

Although we estimate Equation 1 for each cooling capacity class, we need to realize that there is a large variation in sales numbers among the AC models. Diewert (2003), Silver (2002), and Silver and Heravi (2005) summarize the problems of hedonic model analyses and propose using sales value as a weighting variable in the hedonic analysis of POS data. ${ }^{10}$ Following their suggestion, we estimate hedonic models with the weight of sales values. The results are presented in Table 3.

First, the annual electricity consumption of $E C$ shows negative and significant signs in all class models. This result implies that consumers purchase ACs with higher energy efficiency at higher prices. However, the benefit of the electricity saving differs across the AC classes. For instance, while the benefit in the $2.5 \mathrm{~kW}$ class is 44.99 yen, the benefit in the $2.2 \mathrm{~kW}$ class is 98.07 yen.

\footnotetext{
${ }^{9}$ If the rebate was provided for the purchase of a specific AC model, we subtract it from the sales price and use the acquisition price that consumers actually paid in the following analysis.

10 These authors argue that the attributes attached to expensive models with limited numbers of sales are undervalued when the number of sales is used as a weighting variable.
} 
Table 3. Estimation Results of Hedonic Models

\begin{tabular}{|c|c|c|c|c|c|c|c|c|c|c|}
\hline \multirow{3}{*}{$\begin{array}{l}\text { Variable } \\
\text { Constant }\end{array}$} & \multicolumn{10}{|c|}{ Cooling capacity } \\
\hline & \multicolumn{2}{|l|}{$2.2 \mathrm{~kW}$} & \multicolumn{2}{|l|}{$2.5 \mathrm{~kW}$} & \multicolumn{2}{|l|}{$2.8 \mathrm{~kW}$} & \multicolumn{2}{|l|}{$3.6 \mathrm{~kW}$} & \multicolumn{2}{|c|}{$4.0 \mathrm{~kW}$} \\
\hline & 123107.00 & $* * *^{a}$ & 45705.00 & **** & 62982.90 & **** & 209244.00 & $* * *$ & 92023.60 & $* * *$ \\
\hline Annual electricity consumption (EC) & -98.07 & $* * *$ & -44.99 & 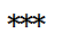 & -46.23 & $* * *$ & -86.40 & $* * *$ & -61.86 & $* * *$ \\
\hline Heating capacity (HEAT) & -2876.44 & & 17080.30 & *kok & 14252.70 & $* * *$ & c & & 18345.20 & **** \\
\hline Physical size (SIZE) & 707.07 & $* * *$ & 612.31 & $* * *$ & 630.36 & $* * *$ & 692.59 & $* * *$ & 719.52 & $* * *$ \\
\hline Days after market release (OLD) & -25.78 & $* * *$ & -41.04 & $* * *$ & -49.86 & $* * *$ & -78.50 & $* * *$ & -59.62 & $* * *$ \\
\hline Ion emission (ION) & 8672.34 & $* * *$ & 3355.44 & 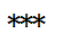 & 6885.82 & $* * *$ & 15795.70 & $* * *$ & 7879.56 & $* * *$ \\
\hline Bacteria elimination (BAC_ELI) & -4779.25 & $* k * k$ & b & & -2511.94 & $* * *$ & 11804.70 & $* * *$ & 1417.30 & $*$ \\
\hline Auto filter cleaning (AUTO_F) & 3909.55 & $* * *$ & 7417.88 & $* * *$ & 9869.44 & $* * *$ & 7956.61 & $* * *$ & 7976.06 & $* * *$ \\
\hline Auto heat exchanger cleaning (AUTO_C) & 4043.70 & $* * *$ & 12391.80 & $* * *$ & 5434.49 & $* * *$ & 5859.10 & $* * *$ & 3156.70 & $* * *$ \\
\hline Humidifier (DEHUM) & 12139.20 & $* * *$ & 13992.00 & $* * *$ & 12321.80 & $* * *$ & 2516.70 & & 8358.15 & $* * *$ \\
\hline Air Control (AIR_CON) & 12552.10 & $* k * k$ & 16940.80 & *kok & 17895.70 & $* * *$ & 7729.85 & $* * *$ & 15223.40 & **** \\
\hline Months after 2008/4 (PERIOD) & -592.79 & $* * *$ & -433.38 & $* * *$ & -296.34 & $* * *$ & -372.51 & $* * *$ & -259.54 & $* * *$ \\
\hline Number of samples & 3,050 & & 2,233 & & 3,208 & & 1,294 & & 3,479 & \\
\hline Adjusted $\mathrm{R}^{2}$ & 0.73 & & 0.77 & & 0.73 & & 0.83 & & 0.77 & \\
\hline
\end{tabular}

The variable $O L D$ becomes negative and statistically significant at the $1 \%$ level in all class models. Hence, old models are priced less. Consumers are concerned with not only the functions of ACs but also the freshness of AC models. The variable PERIOD becomes negative and statistically significant at the $1 \%$ level in all class models. This suggests that the price of ACs declined during the sampling period.

All other functional variables except the bacteria elimination variable $B A C_{-} E L I$ become positive and significant at the $1 \%$ level. This means that the price of ACs increases as an additional function is attached.

\subsection{Choice Model Analysis}

In the choice model, we assume that a consumer who purchased $m^{\text {th }} \mathrm{AC}$ model at period $t$ obtained the following utility,

$$
u_{m t}=\gamma_{0}+\gamma_{A P} A P_{m t}+\gamma_{E C} E C_{m}+\gamma_{O L D} O L D_{m t}+\gamma_{N M} N M_{t}+\boldsymbol{\Gamma} \boldsymbol{X}_{m}+v_{m t} .
$$

Although all unobservable factors are included in the error term $v_{m t}$, some of them may be correlated with the price $A P_{m t}$ or the annual electricity consumption $E C_{m}$. We use a control function approach to resolve this endogeneity problem. More specifically, we estimate the utility function of Equation 3, which adds the control function $\mu_{m t}$ to Equation 2. The derivation of the control function is reported in Appendix 2.

$$
u_{m t}=\gamma_{0}+\gamma_{A P} A P_{m t}+\gamma_{E C} E C_{m}+\gamma_{O L D} O L D_{m t}+\gamma_{N M} N M_{t}+\boldsymbol{\Gamma} \boldsymbol{X}_{m}+\gamma_{\mu} \mu_{m t}+\omega_{m t}
$$

The estimation results are presented in Table 4. Since the bacteria elimination variable $B A C \_E L I$ is correlated perfectly with the ion emission variable $I O N$ in the $2.5 \mathrm{~kW}$ class, we remove the former variable. In addition, for all ACs in the $3.6 \mathrm{~kW}$ class that have the same heating capacity $(H E A T)$ of $4.2 \mathrm{~kW}$, we remove that variable.

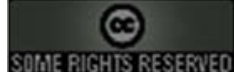


Table 4. Estimation Results of Choice Models

\begin{tabular}{|c|c|c|c|c|c|c|c|c|c|c|}
\hline \multirow{3}{*}{$\begin{array}{l}\text { Variable } \\
\text { Average price }(A P)\end{array}$} & \multicolumn{10}{|c|}{ Cooling capacity } \\
\hline & \multicolumn{2}{|l|}{$2.2 \mathrm{~kW}$} & \multicolumn{2}{|l|}{$2.5 \mathrm{~kW}$} & \multicolumn{2}{|l|}{$2.8 \mathrm{~kW}$} & \multicolumn{2}{|l|}{$3.6 \mathrm{~kW}$} & \multicolumn{2}{|l|}{$4.0 \mathrm{~kW}$} \\
\hline & $-2.591 \mathrm{E}-05$ & $* * *^{a}$ & $-2.566 \mathrm{E}-05$ & $* * *$ & $-2.114 \mathrm{E}-06$ & $* * *$ & $-3.937 \mathrm{E}-05$ & $* * *$ & $-3.246 \mathrm{E}-05$ & $* * *$ \\
\hline Control function ( $\lambda$ & $8.136 \mathrm{E}-06$ & $* * *$ & $1.014 \mathrm{E}-05$ & **** & $-7.249 \mathrm{E}-06$ & $* * *$ & $2.188 \mathrm{E}-05$ & **** & $1.815 \mathrm{E}-05$ & $* * *$ \\
\hline Annual electricity consumption ( $E C)$ & $-9.800 \mathrm{E}-04$ & $* * *$ & $-2.420 \mathrm{E}-03$ & $* * *$ & $-3.500 \mathrm{E}-04$ & $* * *$ & $-5.930 \mathrm{E}-03$ & $* * *$ & $-3.710 \mathrm{E}-03$ & $* * *$ \\
\hline Heating capacity (HEAT) & -1.675 & $* * *$ & -1.648 & **** & -0.510 & $* * *$ & c & & 0.311 & *k*k \\
\hline Physical size (SIZE) & -0.035 & $* * *$ & -0.004 & $* * *$ & -0.019 & $* * *$ & 0.040 & $* * *$ & 0.001 & $* * *$ \\
\hline Days after market release $(O L D)$ & -0.005 & $* * *$ & -0.005 & $* * *$ & -0.003 & $* * *$ & -0.006 & $* * *$ & -0.005 & $* * *$ \\
\hline Ion emission (ION) & 0.014 & $* * *$ & -0.008 & $* *$ & 0.098 & *** & 0.367 & $* * *$ & 0.342 & $* * *$ \\
\hline Bacteria elimination ( $B A C E E L)$ & -0.169 & $* * *$ & b & & -0.197 & $* * *$ & 0.106 & $* * *$ & -0.027 & $* * *$ \\
\hline Auto filter cleaning ( $\left.A \cup T O_{-} F\right)$ & 0.369 & $* * * *$ & 0.320 & **** & 0.011 & $* * *$ & 0.255 & *** & 0.343 & $* * *$ \\
\hline Auto heat exchanger cleaning ( $\left.A U T O_{-} C\right)$ & -0.265 & $* * *$ & 0.034 & $* * *$ & -0.023 & $* * *$ & -0.192 & $* * *$ & 0.314 & **k* \\
\hline Humidifier (DEHUM) & -0.584 & $* * *$ & 0.029 & $* * *$ & -0.465 & $* * *$ & -0.006 & & -0.160 & $* * *$ \\
\hline Air control (AIR CON) & 0.552 & $* * *$ & 0.640 & *** & 0.394 & $* * *$ & 0.515 & $* * *$ & 0.696 & $* * *$ \\
\hline
\end{tabular}

Note. a. $*, * *$, and $* * *$ indicate statistical significance at the $10 \%, 5 \%$, and $1 \%$ levels, respectively.

b. We remove the bacteria elimination variable owing to its perfect correlation with the ion emission variable.

c. We remove the heat capacity variable since there is no variation.

In choice model estimation, the negative coefficient of the specific variable suggests that consumers are more likely to purchase an AC model with a smaller value. By contrast, the positive coefficient suggests that they are more likely to purchase an AC model with a larger value.

First, the price $A P$ becomes negative and significant at the $1 \%$ level in all four models. As we expect, consumers would not purchase an expensive AC if all other functions were the same. Second, annual electricity consumption $E C$ also becomes negative and significant at the $1 \%$ level. This suggests that consumers choose an energy efficient AC if the prices are the same. As mentioned in Section 1, in a choice model, we compare the coefficient of the annual electricity consumption variable with that of the price variable to discuss consumer valuation of energy saving. We provide a discussion of this comparison in Subsection 4.3.

The variable for days after initial sales, $O L D$, becomes negative and statistically significant at the $1 \%$ level. Consequently, consumers would choose a newer model even if all other functions were the same. This result is consistent with the hedonic model analysis.

Although the results of the auto filtering and air control valuables are consistent across all four classes, the results of the remaining variables vary. Finally, the control function becomes significant at the $1 \%$ level. It implies that controlling unobservable factors is important in choice model analyses.

\subsection{Model Comparison}

In the previous two subsections, we examine consumer valuation of energy saving with both hedonic and choice models. In the hedonic model, the "perceived" benefit of the annual electricity saving is estimated to be worth $P B_{E C}=-\beta_{E C}(\mathrm{yen} / \mathrm{kW})$. On the other hand, in the choice model, this saving is estimated to be worth $P B_{E C}=\gamma_{E C} / \gamma_{A P}(\mathrm{yen} / \mathrm{kW})$.

The actual benefit of electricity saving depends on the electricity price. A purchased AC will be used for several years and the electricity price will change during this period of product 
Table 5. Comparison between Hedonic and Choice Models

\begin{tabular}{|c|c|c|c|c|c|}
\hline \multirow[b]{2}{*}{ Cooling capacity } & \multicolumn{2}{|c|}{ Hedonic model } & & \multicolumn{2}{|c|}{ Choice model } \\
\hline & $\begin{array}{c}\text { Payback period } \\
\text { (years) }\end{array}$ & $\begin{array}{l}\text { Implicit discount rate } \\
(\%)\end{array}$ & & $\begin{array}{l}\text { Payback period } \\
\text { (years) }\end{array}$ & $\begin{array}{l}\text { Implicit discount rate } \\
(\%)\end{array}$ \\
\hline $2.2 \mathrm{~kW}$ & 4.5 & & 19.6 & 1.7 & 57.7 \\
\hline $2.5 \mathrm{~kW}$ & 2.0 & & 48.5 & 4.3 & 20.6 \\
\hline $2.8 \mathrm{~kW}$ & 2.1 & & 47.0 & 7.5 & 7.5 \\
\hline $3.6 \mathrm{~kW}$ & 3.9 & & 23.1 & 6.8 & 9.4 \\
\hline $4.0 \mathrm{~kW}$ & 2.8 & & 34.4 & 5.2 & 15.7 \\
\hline
\end{tabular}

usage. Nevertheless, previous studies simply use the electricity price at the time of purchase when calculating implicit discount rates. In this study too, we ignore expectations about the electricity price and simply use the electricity price that a general household paid at the time of the AC purchase. Specifically, we use the electricity price of the Tokyo Electric Power Company, which was $22 \mathrm{yen} / \mathrm{kWh}$.

We initially calculate the payback period by dividing the perceived benefit, $P B_{E C}$, by the electricity price, $P_{E l e}$. The results are presented in Table 5. Although the table shows that the payback period consumers want is $1.7-7.5$ years, this is much shorter than the general usage period of ACs. ${ }^{11}$

When the usage period of an AC is assumed, $T(=11.5)$, and the electricity price is assumed, $P_{E l e}(=22)$, then the implicit discount rate of $\theta(\%)$ is given a value that satisfies the following equality.

$$
P B_{E C}=\sum_{t=0}^{T-1} \frac{P_{E l e}}{\left(1+\frac{\theta}{100}\right)^{t}}
$$

The results are summarized in Table 5. The table shows that implicit discount rates range from $19.6 \%$ to $48.5 \%$ in the hedonic model while they range from $7.5 \%$ to $57.7 \%$ in the choice model. Although these values are larger than those reported in Goett (1983) and Morita, Matsumoto, and Tasaki (2014), they are about the same as that reported in Hausman (1979). See Table 1.

In both hedonic and choice models, the estimated implicit discount rates are much larger than the discount rate used for the general project analyses. Hence, this suggests that a typical consumer underinvests in energy efficiency.

Finally, from the comparison between the two models, we find that hedonic models tend to estimate a larger implicit discount rate than choice models do. The difference is large and the implicit discount rate of the hedonic model is twice as large as that of the choice model.

\section{Conclusions}

Although many studies estimated implicit discount rates during the late 1970s and early 1980 s, only a limited number of studies was conducted thereafter. In this study, we analyzed

${ }^{11}$ Tasaki (2006) examines the usage period of ACs brought to the electronics retail stores for recycling purpose and reported that more than $60 \%$ of ACs were used for 8 years.

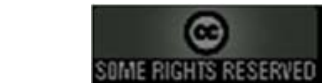


the sales data of residential ACs in the Japanese market to evaluate the consumer valuation of energy saving. We estimated implicit discount rates with both hedonic and choice models and compared the results between the two models.

We found that consumers underinvest in energy saving regardless of the choice of the estimation model. The estimated implicit discount rates range from 7.5\% to 57.7\%. Although many policies have been implemented in recent years to provide consumers with energy efficiency information for home electric appliances, consumers continue to underinvest in energy-saving appliances. Energy efficiency information about ACs is well displayed in electronics retail stores in Japan, and thus, consumers can easily calculate the future electricity cost. Considering these facts, it is very difficult to change the myopic behavior of consumers simply by providing energy efficiency information.

We found that hedonic models estimate a larger implicit discount rate than choice models do. In fact, the difference between the two models is large. Greene (2010) conducted a literature survey about consumer valuation of the fuel economy and reported that the benefits of the fuel economy in hedonic models were larger than those in choice models. Our results are consistent with those of his literature review.

On the other hand, we found that hedonic models provide more consistent results about product attributes than choice models do. Considering the assumptions of the empirical models and the restrictions of the market data, further model comparison would be necessary to understand consumer valuation of energy saving.

\section{Appendix 1. Data Construction}

The primary data are sales data collected by the market research firm GfK Marketing Service Ltd. Based in Japan. It is a member of the GfK group, the fourth largest market research firm in the world, headquartered in Nuremberg, Germany (Gfk, 2015). The data were collected from 4,023 retail stores. The data on ACs cover about 55\% of total annual sales in Japan and include the total value and number of sales of each product as well as the detailed specifications of each product.

ACs are classified according to room size; their cooling capacities show the corresponding room size. There are nine cooling capacity classes. ACs of $2.2 \mathrm{~kW}, 2.5 \mathrm{~kW}$, $2.8 \mathrm{~kW}, 3.6 \mathrm{~kW}, 4.0 \mathrm{~kW}, 4.5 \mathrm{~kW}, 5 \mathrm{~kW}, 5.6 \mathrm{~kW}, 6.3 \mathrm{~kW}$, and $7.1 \mathrm{~kW}$ are designed for rooms of 6 jyo $\left(9.06 \mathrm{~m}^{2}\right), 8$ jyo $\left(12.08 \mathrm{~m}^{2}\right), 10$ jyo $\left(15.10 \mathrm{~m}^{2}\right), 12$ jyo $\left(18.12 \mathrm{~m}^{2}\right), 12$ jyo $\left(18.12 \mathrm{~m}^{2}\right), 14$ jyo $\left(21.14 \mathrm{~m}^{2}\right), 16$ jyo $\left(24.16 \mathrm{~m}^{2}\right), 18$ jyo $\left(27.18 \mathrm{~m}^{2}\right), 20$ jyo $\left(30.20 \mathrm{~m}^{2}\right)$, and 23 jyo $\left(34.73 \mathrm{~m}^{2}\right)$, respectively, in a wooden house. ${ }^{12}$

We initially remove two AC models whose cooling capacities are unknown from the dataset. In a hedonic model, the number of the models needs to be large to analyze the relationship between the price and characteristics of the ACs. Consequently, we focus on the cooling capacity classes of $2.2 \mathrm{~kW}, 2.5 \mathrm{~kW}, 2.8 \mathrm{~kW}, 3.6 \mathrm{~kW}$, and $4.0 \mathrm{~kW}$.

The ACs are classified into general, housing, and business categories. There are only two

12 Jyo is the number of tatami mats. 1 jyo is approximately $1.51 \mathrm{~m}^{2}$.

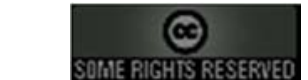


AC models in the housing and business categories. We focus on the general category. The ACs in the housing category are special models installed when new houses are constructed. The prices of the housing AC models are set slightly higher than those of the general models. We discard the AC models whose categories are not recorded in the dataset.

There are three installation modes: placed on floor, ceiling, and wall hanging. We remove the AC models whose installation modes are placed on floor and ceiling as there are only five AC models in these two installation modes. We discard the AC models whose installation modes are not recorded.

Most ACs sold in the Japanese market have space heating functions. In our dataset, only $15 \mathrm{AC}$ models are used exclusively for space cooling. We remove them from the dataset. In addition, we exclude AC models with less than 500 sales units in the entire sample period; they are old models in general.

When the number of sales is recorded as zero, we cannot know whether the AC model was not on sale in the market or nobody purchased it although it was available in the market. Furthermore, the sales price is not recorded in the dataset. Thus, we remove the AC model if the number of sales is zero. We find that the sales values are recoded as zero in the $2.5 \mathrm{~kW}$ cooling capacity class despite positive numbers of sales. We remove two models from September 2010, two models from October 2010, one model from November 2010, five models from December 2010, and three models from January 2011. Since the number of misreported models is large, we remove the entire data of April 2009.

\section{Appendix 2. Control Variable Construction}

Following the approach proposed by Petrin and Train (2010) and Kim and Petrin (2010), we construct the control function as follows.

$\mathrm{AC}$ markets are separated by cooling capacity classes. Consumers choose one AC among the ACs in the specific cooling capacity class suitable for their room. This study uses information of ACs sold in the remaining classes in order to overcome an endogeneity problem.

When analyzing ACs in the $c^{\text {th }}$ cooling capacity class, we use the data of the remaining class $(-c)$ and estimate the following hedonic function

$$
\ln P_{l t}^{-c}=\beta_{0}^{-c}+\beta_{C A P}^{-c} C A P_{l}^{-c}+\beta_{E C}^{-c} E C_{l}^{-c}+B^{-c} \boldsymbol{X}_{l t}^{-c}+\varepsilon_{l t}^{-c} .
$$

Here, $P_{l t}^{-c}$ is the average price of the $l^{t h} \mathrm{AC}$ model at period $t, C A P_{l}^{-c}$ is the cooling capacity, $E C_{\boldsymbol{l}}^{-\boldsymbol{c}}$ is annual electricity consumption, and $\boldsymbol{X}_{l t}$ is the vector of the characteristics of the $l^{\text {th }}$ AC model. We use sales value as a weight. The results are presented in Table 6.

Using the estimated coefficients, we calculate

$$
\ln \hat{P}_{m t}^{c}=\hat{\beta}_{0}^{-C}+\hat{\beta}_{C A P}^{-c} C A P_{\boldsymbol{m}}^{c}+\hat{\beta}_{E C}^{-c} E C_{\boldsymbol{m}}^{\boldsymbol{c}}+\widehat{\boldsymbol{B}}^{-c} \boldsymbol{X}_{m t}^{c}
$$

Plugging this into the exponential function, we estimate the expected price of the $m^{\text {th }} \mathrm{AC}$ model in class $C$

\section{SORIE PIGHIS RESERVED


Table 6. First-Stage Hedonic Analysis (Semi-Log Model)

\begin{tabular}{|c|c|c|c|c|c|c|c|c|c|c|}
\hline Variables & Excluding 2 & $.2 \mathrm{~kW}$ & Excluding 2 . & $5 \mathrm{~kW}$ & Excluding 2 & $8 \mathrm{~kW}$ & Excluding 3 & $6 \mathrm{~kW}$ & Excluding 4. & $0 \mathrm{~kW}$ \\
\hline Constant & 9.936 & $* * * a$ & 9.415 & $* * *$ & 9.389 & $* * *$ & 9.419 & $* * *$ & 9.392 & $* * *$ \\
\hline Cooling capacity $(C A P)$ & 0.139 & $* * *$ & 0.199 & $* * *$ & 0.205 & $* * *$ & 0.194 & $* * *$ & 0.179 & $* * *$ \\
\hline Heating capacity (HEAT) & 8.16E-05 & $* *$ & $-3.04 \mathrm{E}-05$ & & $-7.80 \mathrm{E}-05$ & * & $-3.14 \mathrm{E}-05$ & & $-4.78 \mathrm{E}-05$ & \\
\hline Annual electricity consumption $(E C)$ & $-1.55 \mathrm{E}-05$ & & $1.40 \mathrm{E}-04$ & $* * *$ & $1.80 \mathrm{E}-04$ & $* * *$ & $1.70 \mathrm{E}-04$ & $* * *$ & $1.40 \mathrm{E}-04$ & $* * *$ \\
\hline Days after the market release $(O L D)$ & $-3.40 \mathrm{E}-04$ & $* * *$ & $-3.60 \mathrm{E}-04$ & $* * *$ & $-3.30 \mathrm{E}-04$ & $* * *$ & $-3.50 \mathrm{E}-04$ & $* * *$ & $-3.20 \mathrm{E}-04$ & $* * *$ \\
\hline Physical size (SIZE) & 17.751 & $* * *$ & 21.850 & $* * *$ & 21.511 & $* * *$ & 22.322 & $* * *$ & 23.449 & $* * *$ \\
\hline Ion emission $(I O N)$ & 0.043 & $* * *$ & 0.106 & $* * *$ & 0.106 & $* * *$ & 0.096 & $* * *$ & 0.106 & $* * *$ \\
\hline Bacteria elimination (BAC_ELI) & 0.059 & $* * *$ & 0.091 & $* * *$ & 0.067 & $* * *$ & 0.070 & $* * *$ & 0.068 & $* * *$ \\
\hline Auto filter cleaning $\left(A U T O \_F\right)$ & 0.193 & $* * *$ & 0.158 & $* * *$ & 0.151 & $* * *$ & 0.155 & $* * *$ & 0.156 & $* * *$ \\
\hline Humidifier (DEHUM) & 0.190 & $* * *$ & 0.196 & $* * *$ & 0.204 & $* * *$ & 0.204 & $* * *$ & 0.212 & $* * *$ \\
\hline Air control (AIR_CON) & 0.150 & $* * *$ & 0.151 & $* * *$ & 0.141 & $* * *$ & 0.153 & $* * *$ & 0.158 & $* * *$ \\
\hline Manufacture dummy 1 & -0.383 & $* * *$ & -0.475 & $* * *$ & -0.474 & $* * *$ & -0.483 & $* * *$ & -0.501 & $* * *$ \\
\hline Manufacture dummy 2 & -0.058 & $* * *$ & -0.058 & $* * *$ & -0.023 & $* * *$ & -0.058 & $* * *$ & -0.060 & $* * *$ \\
\hline Manufacture dummy 3 & 0.056 & $* * *$ & 0.015 & $* *$ & 0.020 & $* * *$ & 0.029 & $* * *$ & 0.026 & $* * *$ \\
\hline Manufacture dummy 4 & 0.110 & $* * *$ & 0.053 & $* * *$ & 0.034 & $* * *$ & 0.043 & $* * *$ & 0.030 & $* * *$ \\
\hline Manufacture dummy 5 & -0.012 & $* *$ & -0.099 & $* * *$ & -0.093 & $* * *$ & -0.106 & $* * *$ & -0.118 & $* * *$ \\
\hline Manufacture dummy 6 & -0.006 & & -0.142 & $* * *$ & -0.112 & $* * *$ & -0.148 & $* * *$ & -0.161 & $* * *$ \\
\hline Manufacture dummy 7 & -0.098 & $* * *$ & -0.077 & $* * *$ & -0.144 & $* * *$ & -0.085 & $* * *$ & -0.088 & $* * *$ \\
\hline Manufacture dummy 8 & 0.099 & $* * *$ & 0.156 & $* * *$ & 0.152 & $* * *$ & 0.148 & $* * *$ & 0.165 & $* * *$ \\
\hline Manufacture dummy 9 & 0.001 & $* * *$ & 0.001 & $* * *$ & 0.002 & $* * *$ & 0.001 & $* * *$ & 0.002 & $* * *$ \\
\hline 2009 year dummy & 0.009 & $* *$ & 0.003 & & -0.001 & & 0.003 & & 0.003 & \\
\hline 2010 year dummy & -0.002 & & -0.003 & & -0.006 & $*$ & -0.008 & $* *$ & -0.016 & $* * *$ \\
\hline 2011 year dummy & 0.038 & $* * *$ & 0.027 & $* * *$ & 0.023 & $* * *$ & 0.021 & $* * *$ & 0.011 & \\
\hline Adjusted $\mathrm{R}^{2}$ & 0.872 & & 0.898 & & 0.915 & & 0.892 & & 0.886 & \\
\hline Number of samples & 13,568 & & 14,385 & & 13,410 & & 15,324 & & 13,139 & \\
\hline
\end{tabular}

Note. a. $* * *$, and $* * *$ indicate statistical significance at the $10 \%, 5 \%$, and $1 \%$ levels, respectively.

$$
E\left[P_{m t}^{c}\right]=\exp \left(\ln \hat{P}_{m t}^{c}\right)
$$

Using $E\left[P_{m t}^{c}\right]$ as an instrumental variable, we estimate the following hedonic function

$$
P_{m t}^{c}=\alpha^{c}+\beta_{E} E C_{m}^{c}+\Gamma^{c} \boldsymbol{X}_{m t}^{c}+\zeta_{E P} E\left[P_{m t}^{c}\right]+\varepsilon_{m t}^{c}
$$

Finally, we calculate the residual of this estimation

$$
\mu_{m t}=P_{m t}^{c}-E\left[P_{m t}^{c}\right]
$$

We use this as a control function in Equation 3.

\section{Acknowledgement}

Most of this paper was written during my sabbatical at the Institute for Environmental Science and Technology (ICTA) at the Universitat Autònoma de Barcelona in the 2015 academic year. I would like to thank ICTA for its great hospitality. This work is supported financially by the Asahi Glass Foundation and the Japan Society for the Promotion of Science KAKENHI (Grant Number: 26340119).

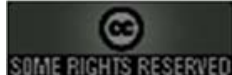




\section{References}

Arthur D. Little, Inc. (1984) "Measuring the impact of residential conservation programs: an econometric analysis of utility data," Volume III, Final Report for RP1587, Electric Power Research Institute, California.

Arguea, N.M, Hsiao, C., and Taylor, G.A. (1994) "Estimating consumer preferences using market data-An application to U.S. automobile demand," Journal of Applied Econometrics Vol.9, No.1, pp.1-18.

Berkovec, J., Hausman, J., and Rust, J. (1983) "Heating system and appliance choice," Report No. MIT-EL 83-004WP, MIT Energy Laboratory, Cambridge, MA.

Cambridge Systematics, Inc. and Charles River Associates, Inc. (1988) "Investments in conservation measures," Vol.1, Implicit Discount Rates in Residential Customer Choices, EPRI EM-5587, Electric Power Research Institute, California.

Cohen, F., Glachant, M., and Söderberg, M. (2014) "The impact of energy prices on energy efficiency: Evidence from the UK refrigerator market," TIGER Forum 2014: Ninth Conference on Energy Industry at a Crossroads: Preparing the Low Carbon Future, Toulouse, France, June 5-6.

Cole, H. and Fuller, R. (1980) "Residential energy decision-making: An overview with emphasis on individual discount rates and responsiveness to household income and prices," Report prepared by Hittman Associates, Inc., Columbia, MD.

Corum, K.R. \& O'Neal, D.L. (1982) "Investment in energy-efficient houses: An estimate of discount rates implicit in new home construction practices," Energy Vol.7, No.4, pp.389400.

Diewert, E. (2003) "Hedonic regressions: A review of some unsolved issues," Paper presented at conference on research in income and wealth. National Bureau of Economic Research, available at, http://www.nber.org/CRIW/papers/diewert.pdf (accessed on August 4 2014)

Dubin, J.A. (1985) Consumer Durable Choice and the Demand for Electricity. New YorkAmsterdam: North-Holland Publishing Co.

Dubin, J.A. (1986) "Will mandatory conservation promote energy efficiency in the section of household appliance stocks?" The Energy Journal Vol.7, pp.98-118.

Dubin, J.A. (1992) "Market barriers to conservation: Are implicit discount rates too high?" No. 802, Working Paper, California Institute of Technology, Division of the Humanities and Social Sciences.

Espey, M. and Nair S. (2005) "Automobile fuel economy: What is it worth?" Contemporary Economic Policy Vol.23, No.3, pp.317-323.

Fan, Q. and Rubin, J. (2009) "Two-stage hedonic price model for light-duty vehicles: Consumers' valuation of automotive fuel economy in Maine," Journal Transportation Research Record: Journal of the Transportation Research Board Vol. 2157 / 2010 Travel Behavior 2010, Vol.2, pp.119-128.

Fifer, D.P.C. and Bunn, N.P. (2009) "Assessing consumer valuation on fuel economy in auto markets," Honors Thesis, Department of Economics, Due University, Durham, North Carolina.

Gately, D. (1980) "Individual discount rates and the purchase and utilization of energy-using durables: Comment," Bell Journal of Economics Vol.11, No.1, pp.373-374.

GfK. (2015) "Retail Sales Tracking," available at: < http://www.gfk.com/solutions/retail-salestracking/Pages/default.aspx $>$ (accessed on January 26, 2015).

Goett, A. (1978) "Appliance fuel choice: An application of discrete multivariate analysis," Ph.D. thesis, Department of Economics, University of California at Davis.

Goett, A. (1983) "Household appliance choice: Revision of REEP behavioral models," Final 
Report for Research Project 1918-1, Electric Power Research Institute, California.

Goett, A. and McFadden, D. (1982) "Residential energy-use planning system (REEPS), Report EA-2512, Electric Power Research Institute, California.

Greene, D.L. (2010) "How consumers value fuel economy: A literature review," EPA-420-R10-008. United States Environmental Protection Agency. March 2010.

Hausman, J. (1979) "Individual discount rates and the purchase and utilization of energy-using durables," Bell Journal of Economics Vol.10, No.1 pp.33-54.

Jaffe, A.B. and Stavins, R.B. (1994) "The energy paradox and the diffusion of conservation technology," Resource and Energy Economics Vol.16, No.2, pp.91-122.

Japan Refrigeration and Air Conditioning Industry Association. (2014) "About annual electricity consumption," available at: $<$ http://www.jraia.or.jp/product/home_aircon/e_saving_energy.html $>$ (accessed on March $8,2015)$.

Kim, K. and Petrin, A. (2010) "Control function corrections for omitted attributes in differentiated product models," University of Minnesota working paper, available at: $<$ http://www.econ.umn.edu/ p petrin/research.html $>$ (accessed December 8, 2012).

Lin, W., Hirst, E., and Cohn, S. (1976) "Fuel choice in the household sector," Oak Ridge National Laboratory Report ORNL/CON-2.

Matsumoto, S. and Omata, Y. (2015) "Consumer valuation of energy-efficiency investment: The case of Vietnamese air conditioner market." RIETI Discussion Paper Series, Research Institute of Economy, Trade and Industry, available at: <http://www.rieti.go.jp/en/> (accessed on June 10, 2015).

McManus, W. (2007) "The link between gasoline prices and vehicle sales: Economic theory trumps conventional Detroit wisdom," Business Economics Vol.42, No.1, pp.54-60.

Meier, A.K., and Whittier, J. (1983) "Consumer discount rates implied by purchases of energyefficient refrigerators," Energy Vol.8, No.12, pp.957-962.

Morita, M., Matsumoto, S., and Tasaki, T. (2014) "Effect of an energy rebate program on implicit discount rate: A hedonic analysis of the Japanese Eco Point Program," Review of Environmental Economics and Policy Studies Vol.7, No.2. pp.24-36 (in Japanese).

Palmquist, R.B. and Israngkura, A. (1999) "Valuing air quality with hedonic and discrete choice models," American Journal of Agricultural Economics Vol.81, No.5 Proceedings Issue, pp.1128-1133.

Petrin, A. and Train K. (2010) "A control function approach to endogeneity in consumer choice models," Journal of Marketing Research Vol.47, pp.3-13.

Revelt, D. and Train, K. (1998) "Mixed logit with repeated choices: households' choices of appliance efficiency level," Review of Economics and Statistics Vol.80, No.4 pp.647-657.

Sanstad, A.H., Hanemann, W.M., and Auffhammer, M. (2006) "End-use energy efficiency in a 'post-carbon' California economy: Policy issues and research frontiers," in Hanemann, M.W. and Farrell, A.E. (eds.) Managing Greenhouse Gas Emissions in California, Chapter 6. The California Climate Change Center, University of California, Berkeley.

Silver, M. (2002) "The use of weights in hedonic regressions: The measurement of quality adjusted price changes," mimeo, Cardiff Business School, Cardiff University.

Silver, M. and Heravi S. (2005) "A failure in the measurement of inflation: Results from a hedonic and matched experiment using scanner data," Journal of Business and Economic Statistics Vol.23, No.3, pp.269-281.

Tasaki, T. (2006) "An evaluation of actual effectiveness of the recycling law for electrical home appliances. No. 191. National Institute of Environmental Studies. Available at: < http://www.nies.go.jp/kenkyusaizensen/r-191-2006.pdf> (accessed on March 15, 2015).

Train, K. (1985) 'Discount rates in consumers' energy-related decisions: A review of the literature,” Energy Vol.10, No.12, pp.1243-1254. 
US Energy Information Administration. (2011) "International Energy Statistics," available at: $<$ http://www.eia.gov/cfapps/ipdbproject/iedindex3.cfm?tid $>$ (accessed on March 20, 2015).

Veblen, T. (1899) Theory of the Leisure Class, Oxford University Press, UK (October 11, 2007). 